\title{
Analysis of kinetic data in industrial steel converter for the operation control
}

\author{
C. Blanco, E. García, M. Rendueles, M. Díaz (University of Oviedo) \\ L.-F. Sancho (Arcelor Avilès)
}

The steel converter constitutes a multiphase process, operating in a batch two liquid phases, with a gas continuous phase. Several set points for the different components reacting inside are introduced to have the controlled process achieve a high quality product. Results of industrial converter operation have been analyzed looking for the evolution of the main important components $\mathrm{C}, \mathrm{Si}, \mathrm{Mn}, \mathrm{S}, \mathrm{P}$ from the beginning to the minutes 12 and 15 , as well as the evolution of carbon compounds in the gas phase. Proposed kinetics in the literature for the different components have been used to analyse results, obtaining equations for the prediction of the parameters. Besides, some interesting results appear from the results of the evolution of the gas phase. The obtained kinetics can be used for the simulation of new operational blowing to compare results with the existing control methods, and also to establish if given load will give good final quality product, or which blowing strategy will be needed.

Object of a presentation at the $5^{\text {th }}$ European Oxygen Steelmaking Conference EOSC 2006, organized by Steel Institute VDEh, 26-28 June, 2006.

\section{INTRODUCTION}

Steel converter is key equipment in the steel industry, and one of the biggest reactors in use. Knowledge of the different reactions is very important for the sake of operation efficiency and economy (1). Many kinetic works have been carried out in the laboratory, studying individual reactions under selected conditions, looking for the controlling steps and for the effect of the process variables. Inside the industrial process, a number of variables are interacting, changes of phases and temperature evolution included, so that the important economic aim of the prediction of the final products characteristics from knowledge of the materials loading and blowing strategy, remains a subject for constant improvement. A simplified scheme of the industrial steel converter is presented; it shows that, as a multiphase system, it features different reaction zones (2).

The slag phase volume and the foam as well change through the process, thus introducing additional problems. They affect many aspects, including reactions, and other parameters such as the noise. The aim of this work is to obtain kinetics or prediction equations, based on mechanisms described in the literature and on the results of an industrial installation. They can be used to define the strategies of additives needed, or blowing strategies and control processes to obtain a high quality product.

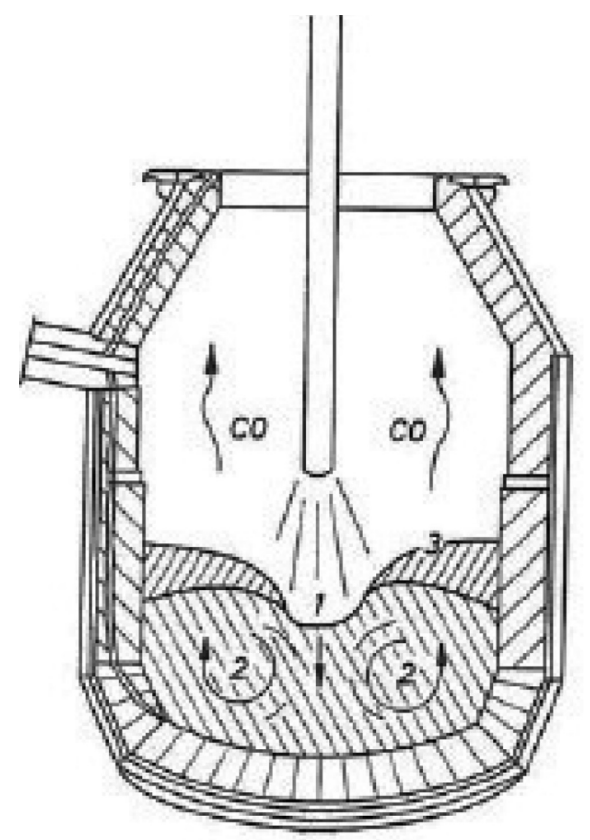

Fig. 1 - Steel converter with different reaction zones. Fig. 1 - Les différentes zones de réaction au convertisseur. 


\title{
Analyse des données cinétiques au convertisseur pour le contrôle de l'affinage
}

\author{
C. Blanco, E. García, M. Rendueles, M. Díaz (University of Oviedo) \\ L.-F. Sancho (Arcelor Avilès)
}

L'affinage au convertisseur est contrôlé par le réglage des enfournements et la stratégie de soufflage pour atteindre la composition visée. Des résultats obtenus en aciérie ont été analysés pour suivre l'évolution des teneurs des principaux éléments en cours d'affinage ainsi que les émissions de gaz.

Les concentrations en carbone et autres éléments pendant l'affinage peuvent être modélisées selon différentes approches. Les méthodes évaluées sont de nature statistique ou à base de calculs stoechiométriques. Des mécanismes plus complexes doivent être pris en compte pour intégrer simultanément les cinétiques spécifiques des équilibres en $\mathrm{C}$ et $\mathrm{Si}$, celles des autres éléments ou encore l'équilibre d'énergie.
Le choix des paramètres thermodynamiques du modèle doit être justifié non seulement par l'erreur observée mais aussi par la rigueur scientifique des hypothèses de calcul et la comparaison avec l'expérience et les résultats sur maquette.

Les modèles cinétiques qui ont été développés peuvent être utilisées en particulier pour la définition de nouvelles stratégies d'affinage.
TABLE I: Indicative chemical data.

TABLEAU I: Compositions indicatives.

\begin{tabular}{|l|c|c|c|c|c|c|}
\hline w\% & $\mathrm{Fe}$ & $\mathrm{C}$ & $\mathrm{Si}$ & $\mathrm{P}$ & $\mathrm{S}$ & $\mathrm{Mn}$ \\
\hline Molten iron & 95.0 & 4.5 & 0.4 & 0.07 & 0.02 & \\
\hline Scrap & 99.2 & 0.2 & 0.1 & 0.05 & & 0.4 \\
\hline Additives & \multicolumn{7}{|c|}{ Lime, Dolomite, Fluospar, Sinter. } \\
\hline
\end{tabular}

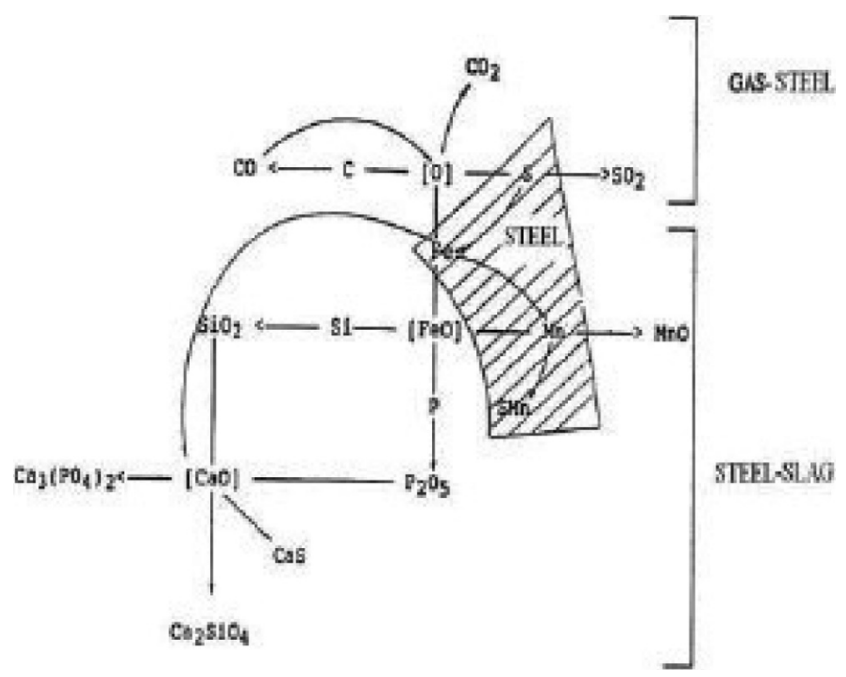

Fig. 2 - Phases involved in the reactions in the converter.

Fig. 2 - Phases impliquées dans les réactions au convertisseur.

\section{ANALYSIS OF THE SYSTEM}

The capacity of the industrial converter is of 250 ton, the melt load being $1 / 5$ of the available volume of the converter. The blowing lance with four holes blows around $850 \mathrm{Nm}^{3}$ of oxygen per minute at a pressure of 8-10 atmospheres. The height of the lance over the bath (liquid phases) ranges from 3.8 to $1.8 \mathrm{~m}$ over the surface, decreasing according to a controlled trajectory. Indicative chemical data are presented in table I.

Reactions between different reactants are mainly multiphase in nature, with an important participation of mass transport phenomena. Some of the important interactions between the three phases are indicated in figure 2. A high number of reactions occur, some of them less important, depending also on the phase under consideration. A simple relation of them is shown in table II.

From the matrix of stoichiometric coefficients, eleven equations are linearly independent. The three phases and the three reaction agents $\left(\mathrm{O}_{2}, \mathrm{FeO}\right.$ and added lime) participate in the different existing mechanisms, for example in the first minutes of the process on the fast and exothermal silicon removal with oxygen or $\mathrm{FeO}$ as reactants. The same happens for the carbon. Manganese presents a more complex evolution because of its reversion and depends on temperature and slag interactions. Phosphorus depends also in both mechanism, and sulphur can be removed through the slag or the fumes. Evolution of the temperature and interfacial areas through blowing time, are key parameters to explain evolution of the components, the case of sulphur or even manganese, are key 
subjects to explain the curve-shape evolution with time $(3,4)$. For the different components $\left(\mathrm{SiO}_{2}, \mathrm{FeO}, \mathrm{CaO}\right.$,.. $)$ of the process, "equilibrium" relations have been published in the literature, that we have assessed against the measured composition in the final step of the reaction. The fit for the different components can be displayed, as the one for sulphur in figure 3.

\section{ANALYSIS FOR C AND SI EVOLUTION}

A simplified mechanism can be assumed as a transfer of oxygen from gas to the steel phase where $\mathrm{O}_{2}$ solubility is $\mathrm{c}^{*}{ }_{\mathrm{A}}$. If the carbon concentration in the steel phase $\mathrm{c}$ is higher than $\left(\mathrm{vk}_{\mathrm{L}} \mathrm{a} \mathrm{c}{ }_{\mathrm{A}} / \mathrm{k}\right)$, there will be a diffusion regime $\mathrm{DR}$, while the control is kinetic KR, in the contrary case. The volumetric mass transfer coefficient $\mathrm{k}_{\mathrm{L}}$ a will be determinant in the diffusion regime, while the kinetic constant $\mathrm{k}$ (first order assumed) will be determinant in kinetic regime of the reaction of stoichiometry coefficient $\mathrm{v}$.

The observed removal rate will be constant with high carbon concentration (DR) in the first minutes, and reducing afterwards proportional to the reduction of the $\mathrm{C}$ concentration, at the end, with low concentrations. Estimation of $\mathrm{k}$ and $\mathrm{k}_{\mathrm{L}} \mathrm{a}$ values (around 8 and $2 \mathrm{~min}^{-1}$ respectively) give a good tool to know the limits of operation and the interest to increase agitation and oxygen supply $(5,6)$. Additional improvements of the model are: first, the improvement or fitting of the solubi-

TABLE II: Important considered reactions in the process.

TABLEAU II: Les principales réactions du process.

\begin{tabular}{|c|}
\hline $\begin{array}{l}\text { GAS/STEEL REACTIONS } \\
\underline{C}+\underline{O} \rightarrow \mathrm{CO}(\mathrm{g})\end{array}$ \\
\hline $\mathrm{CO}+\mathrm{O}_{2} \rightarrow \mathrm{CO}_{2}(g)$ \\
\hline$\underline{\mathrm{Fe}}+\underline{\mathrm{O}} \rightarrow \mathrm{FeO}$ \\
\hline $\mathrm{S}+\mathrm{O}_{2} \rightarrow \mathrm{SO}_{2}(g)$ \\
\hline STEEL/SLAG REACTIONS \\
\hline$\underline{C}+(\mathrm{FeO}) \rightarrow \underline{\mathrm{Fe}}+\mathrm{CO}(g)$ \\
\hline$\underline{\mathrm{Mn}}+(\mathrm{FeO}) \rightarrow \underline{\mathrm{Fe}}+\mathrm{MnO}(g)$ \\
\hline $2 \underline{P}+5(\mathrm{FeO}) \rightarrow 5 \underline{F e}+\left(P_{2} \mathrm{O}_{5}\right)$ \\
\hline$P_{2} \mathrm{O}_{5}+3(\mathrm{CaO}) \rightarrow \mathrm{Ca}_{3}\left(\mathrm{PO}_{4}\right)_{2}$ \\
\hline$\underline{\mathrm{Si}}+2(\mathrm{FeO}) \rightarrow\left(\mathrm{SiO}_{2}\right)+2 \underline{\mathrm{Fe}}$ \\
\hline $\mathrm{SiO}_{2}+2(\mathrm{CaO}) \rightarrow\left(\mathrm{Ca}_{2} \mathrm{SiO}_{4}\right)$ \\
\hline$\underline{\mathrm{SFe}}+(\mathrm{MnO}) \rightarrow \mathrm{SMn}+(\mathrm{FeO})$ \\
\hline$\underline{\mathrm{SFe}}+(\mathrm{CaO}) \rightarrow(\mathrm{CaS})+(\mathrm{FeO})$ \\
\hline STEEL/STEEL REACTIONS \\
\hline$\underline{\mathrm{SFe}}+\underline{\mathrm{Mn}} \rightarrow \underline{\mathrm{SMn}}+\underline{\mathrm{Fe}}$ \\
\hline
\end{tabular}

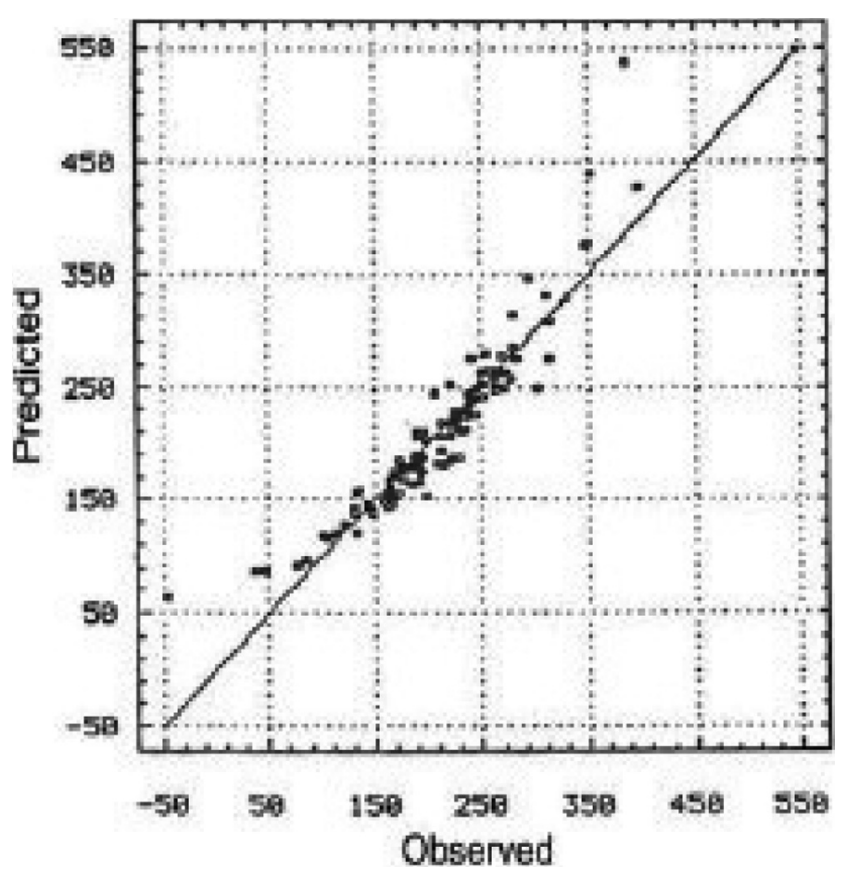

Fig. 3 - Results of sulphur predicted by "equilibrium" reactions vs. the experimentally observed in the plant.

Fig. 3 - Comparaison des teneurs en soufre calculées par des modèles "à l'équilibre" et les teneurs obtenues à l'aciérie.

lity value $\mathrm{c}_{\mathrm{A}}^{*}$, and secondly the introduction of the silicon removal consideration. The silicon will give $\mathrm{SiO}_{2}$ (to be fixed in $\mathrm{CaO}$ ) with similar limitation rate than $\mathrm{C}$, but faster, when increasing temperature. In this case the $\mathrm{k}$ value will be lower $\left(\right.$ around $5 \mathrm{~min}^{-1}$ ). An indication of the predicted evolution is given in figure 4.

Although the previous models are convenient for prediction and control reasons, it is appropriate to indicate the assets of

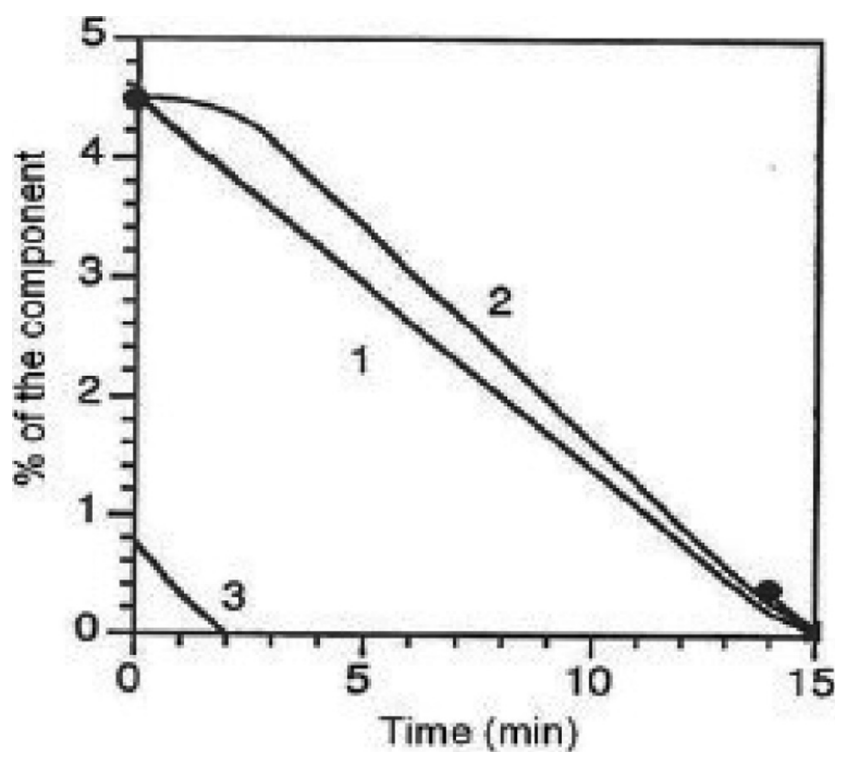

Fig. 4 - Predicted profiles for silicon [3] and carbon, basic [1] and improved models [2].

Fig. 4 - Profils calculés du silicium [3] et du carbone par les modèles de base [1] et amélioré [2]. 
other feasible models. It takes into consideration that carbon can be removed through slag (not through the gas phase). Thus, an equation considering instantaneous irreversible reaction between the two liquid phases could be adequate to fit the results. It is then estimated that kinetic considerations would be limiting and a first order equation would appear. The $\mathrm{k}_{\mathrm{L}} \mathrm{a}$ value between the two liquid phases can be considered initially as a constant. The errors introduced by this model appear to be not very different from those of the model of reaction with the gas phase.

\section{EVOLUTION OF SECONDARY COMPONENTS}

Although not of main interest, carbon removal happens simultaneously to the evolution of the other components, being important for control, besides the effect in the secondary metallurgy.

The concave shape of the evolution of sulphur with time may possibly be explained by an increase of the interfacial area (under mass transfer limitation) or temperature increase (under kinetic control) through the blowing time. In the first case, assuming $\mathrm{k}_{\mathrm{L}}=7.9 \times 10^{-8} \mathrm{~m} / \mathrm{min}$, L-L interfacial areas of $4000 \mathrm{~m}^{-1}$ should be available in the final times. In the second hypothesis, fitting the available data can be obtained with activation energy $E_{A}=63.0 \mathrm{kcal} / \mathrm{mol}$. This is only an example of how different assumptions can be used when different control processes are considered.

For phosphorus, the reaction in the steel-slag interphase looks predominant, and its distribution coefficient between steel and slag is a key parameter. Another essential factor is the $\mathrm{k}_{\mathrm{L}}$ a value between the liquid phases that ranges around $0.005 \mathrm{~min}^{-1}$. It is also highly dependent on the basicity and temperature; the low temperature favours $\mathrm{P}$ removal.

For manganese, that reacts reversibly with $\mathrm{FeO}$, the profile shape is nearly inverted to the one of Fe evolution indicated in figure 5. Kinetic equations are depending on L-L mass transfer, besides diffusivity and Fe solubility. In all this process, as in the $\mathrm{P}$ removal, the key is the formation of $\mathrm{FeO}$ that depends at least on the gas mass transfer and total power input, highly affected by bottom blowing and the height of the lance $(7,8,9)$.

\section{MODELS FOR MULTI COMPONENT SYSTEM}

A first type of models that can be directly used for control objectives are based on developing and adapting statistical previous models. The key in this case is to select the variables to be included. The main variables to be considered are: in the molten iron and steel (C, Si, Mn, P, S); in the blowing operation ( $\mathrm{T}$, blowing time, $\mathrm{O}_{2}$, lance height); and in the composition of the additives and slag $\left(\mathrm{SiO}_{2}, \mathrm{MnO}, \mathrm{P}_{2} \mathrm{O}_{5}, \mathrm{MgO}, \mathrm{S}\right.$, $\mathrm{CaO}, \mathrm{MgO}, \mathrm{Fe}, \mathrm{Al}_{2} \mathrm{O}_{3}, \mathrm{TiO}_{2}$ ). Good correlation between simulated and experimental results is obtained, the equations being useful, but meaningless.

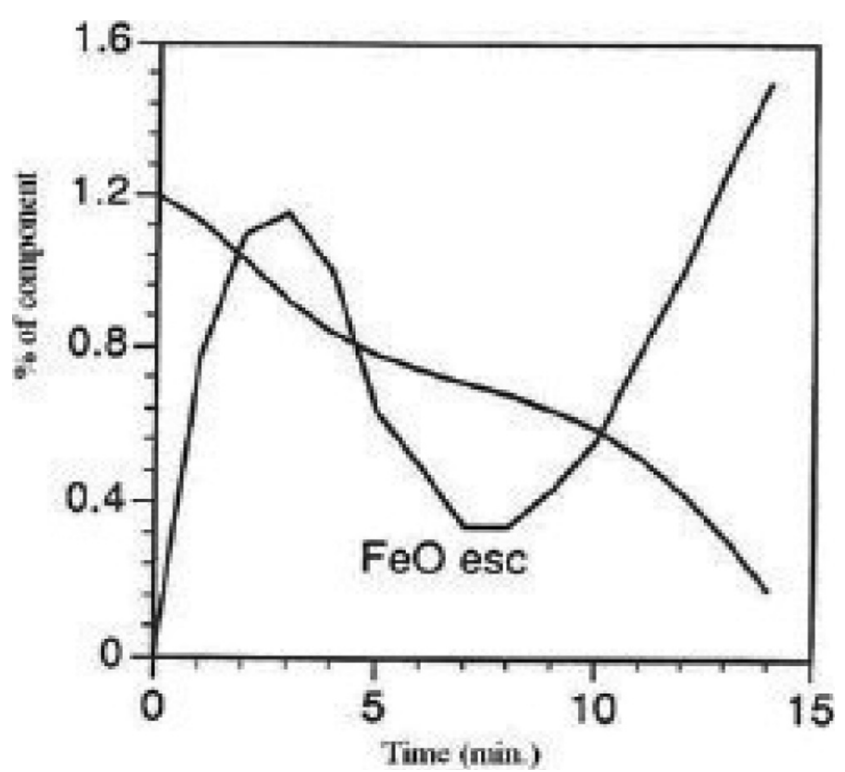

Fig. 5 - Prediction of $\mathrm{P}$ and $\mathrm{FeO}$ with time.

Fig. 5 - Prévisions du P et du FeO en fonction du temps.

Some final conclusions of the analysis are presented in table III with the most important variables to correlate the changes in composition. This can be useful for empirical control operation, even for qualitative indications.

A second and interesting model is to approach the system with average temperature conditions. This can be an adequate approach, considering the complexity of the process, and the possibility of using adaptive models for the control, leaving free one or two parameters, to be fitted using the more recent experimental data. It can be also convenient when considering the dynamic character of the converter, changing many parameters, for example the characteristics of the materials, or the change in the volume of the converter due to the erosion of the walls (10).

\section{TABLE III: Variables more important to justify element changes.}

TABLEAU III: Facteurs principaux corrélés aux évolutions de composition.

\begin{tabular}{|c|c|}
\hline Element & Variables \\
\hline$C_{f}$ & -IIM, -SLI, +CAL, +molten iron \\
\hline $\mathrm{Mn}_{\mathrm{f}}$ & -IIM, -SL, -SLF, $+\mathrm{T}_{\mathrm{ARR}}$, -Sinter, -Scrap, $+\mathrm{MnO}$ \\
\hline $\mathrm{P}_{2} \mathrm{O}_{5}$ & $-\mathrm{Si}_{0},+$ Scrap \\
\hline $\mathrm{MnO}$ & +MnO, -Lime, +Scrap, +molten iron \\
\hline $\mathrm{MgO}$ & +Dolomite Cr, -Scrap, +SLI, +SLF \\
\hline $\mathrm{Fe}$ & -SLI, -SLF, +Lime, +molten iron \\
\hline $\mathrm{CaO}$ & -SLI, -SLF, +Lime, +molten iron, $+\mathrm{T}_{\mathrm{ARR}}$ \\
\hline \multirow[t]{2}{*}{$\mathrm{SiO}_{2}$} & $+\mathrm{Si}_{\mathrm{O}}$, $-\mathrm{SLI},-\mathrm{SLF},+$ molten iron, $+\mathrm{T}_{\mathrm{ARR}}$ \\
\hline & Interesting relations \\
\hline $\mathrm{Si}_{\mathrm{F}} / \mathrm{Si}_{\mathrm{O}}$ & $+\mathrm{Co},-\mathrm{Si}_{\mathrm{O}},-\mathrm{MnO}$ \\
\hline $\mathrm{S}_{\mathrm{f}} / \mathrm{S}_{\mathrm{O}}$ & + Scrap, $-\mathrm{Si}_{\mathrm{O}},+\mathrm{T}_{\mathrm{ARR}}$ \\
\hline
\end{tabular}


TABLE IV: Kinetic equations involved.

TABLEAU IV: Equations cinétiques pertinentes.
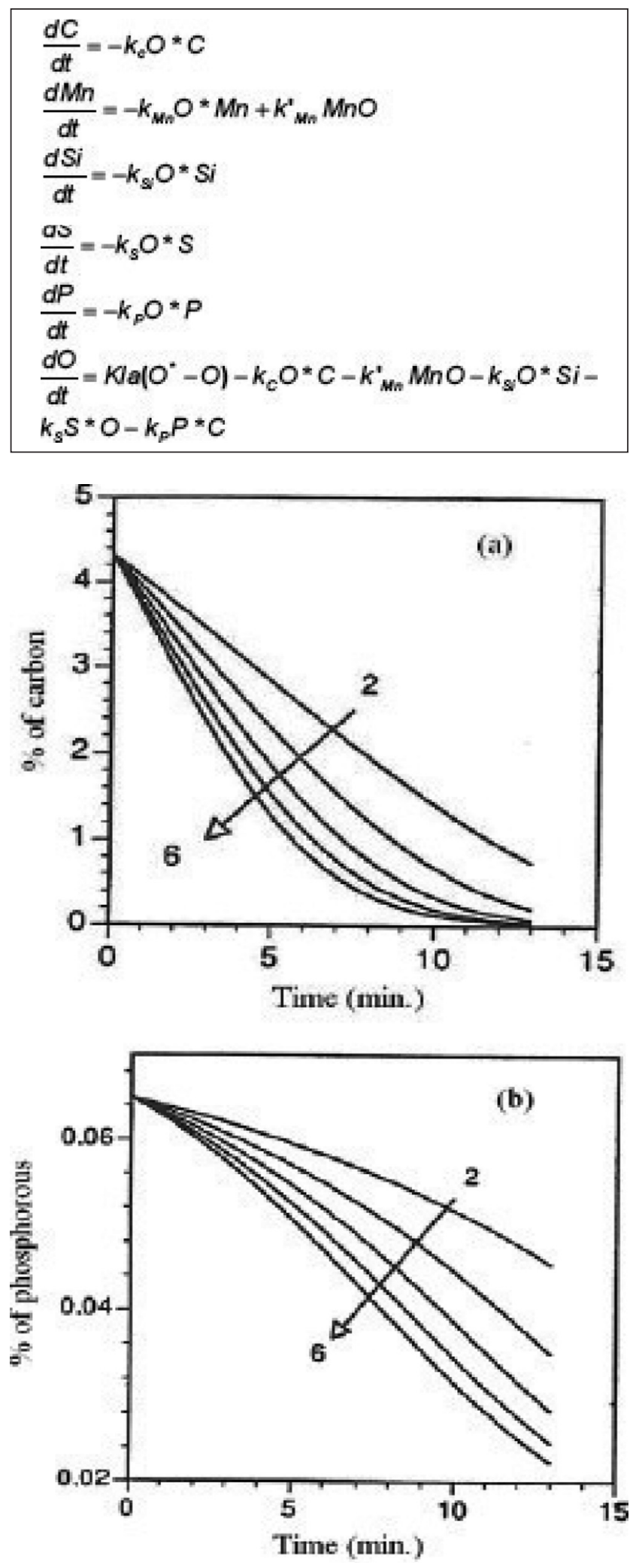

Fig. 6 - Trajectories of $C(a)$ and $P(b)$ as a function of $K_{L} a\left(\mathrm{~min}^{-1}\right)$.

Fig. 6 - Evolutions de $\mathrm{C}$ (a) et de $\mathrm{P}(\mathrm{b})$ en fonction de $\mathrm{K}_{\mathrm{L}} \mathrm{a}\left(\mathrm{min}^{-1}\right)$.
Equations in table IV are used to adjust the constants optimizing the results, from some initial values, using also the order of magnitude that was obtained from the analysis made for the individual component.

The effect of the $\left(\mathrm{k}_{\mathrm{L}} \mathrm{a}\right)_{\mathrm{G} / \mathrm{L}}$ value on the evolution of $\mathrm{C}(6 . \mathrm{a})$ and $\mathrm{P}(6 . \mathrm{b})$ is presented in figure 6 .

\section{THE BALANCE OF ENERGY}

Temperature changes sharply through the blowing, besides changes in the physical state of some materials. Thus, the energy balance is essential to draw a more complete status of the system. Nevertheless, several assumptions have to be made, and many other thermodynamic properties, such as those of state change, are needed in the energy balance:

$\frac{d H_{\text {wat }}}{d t}=-Q_{g a s}-Q_{r a d}-Q_{\text {cond }}$

In spite of this complexity, due to industrial variability and assumptions of the model, many other errors will remain. The mass balance includes the mass transfer besides the chemical kinetics and are indicated in table $V$.

The two main volumetric mass transfer coefficients G-L and L-L' are function of the gas flow rates and of the height of the lance (besides the "average" temperature in the converter). Once the parameters were obtained from the test blowing, the

TABLE V: Equations analyzed in the first proposal for multi components.

TABLE V: Equations de la première approche multi composants.

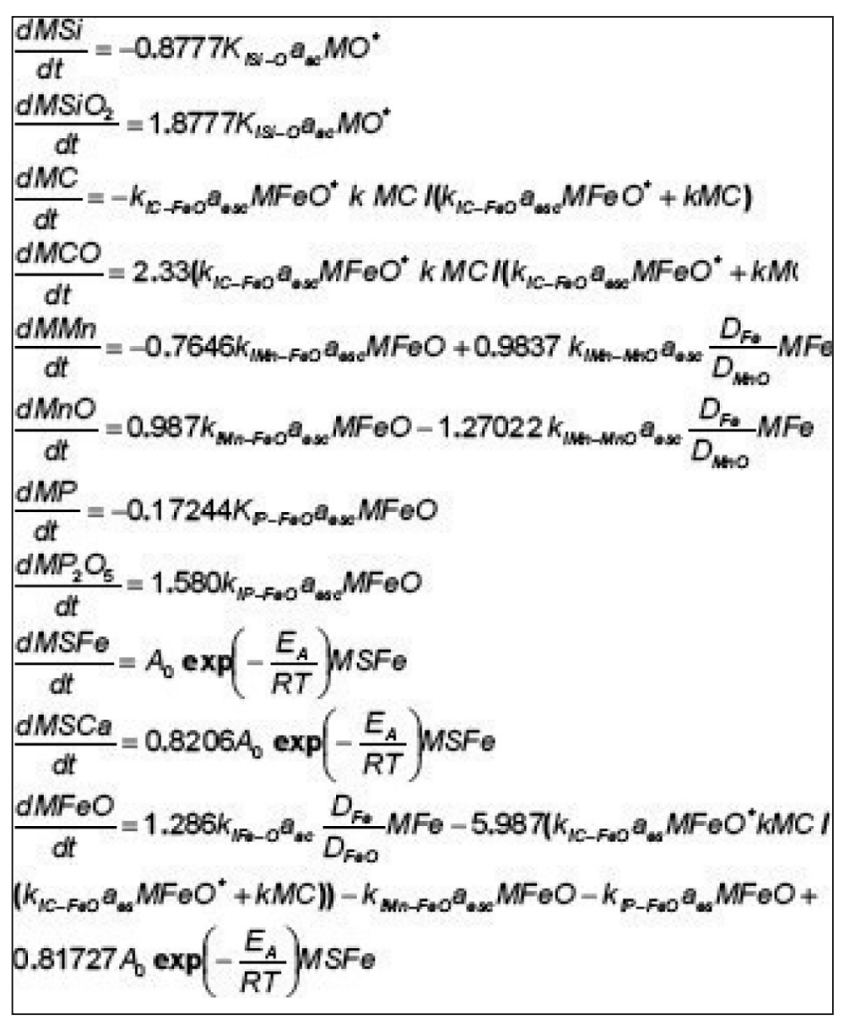


TABLE VI: Average errors with optimized parameters.

TABLEAU VI: Erreurs moyennes avec les paramètres optimisés.

\begin{tabular}{|c|c|c|c|c|c|}
\hline $\mathrm{C}$ & $\mathrm{S}$ & $\mathrm{T}$ & $\mathrm{Mn}$ & $\mathrm{P}$ & $\mathrm{Si}$ \\
\hline $20 \%$ & $15 \%$ & $3 \%$ & $25 \%$ & $31 \%$ & $\begin{array}{c}\text { low, } \\
\text { "total removal" }\end{array}$ \\
\hline
\end{tabular}

equations were assessed with the optimized parameters against new blowings. The average errors that have been obtained for different parameters are indicated in table VI.

As an example the effect of changing lime addition from 7 to 11 ton, on the evolution of $\mathrm{Mn}$ and $\mathrm{S}$ is presented in figure 7.

A small summary on the effect of the additives that is obtained with the model is given in table VII.

The result obtained, if expressed in terms of what effects each component, is a useful tool to decide on the most appropriate operation of the converter, besides it is a test to improve the model.

Another interesting consequence can be obtained looking for the best strategy to combine height of the lance and gas flow rate to obtain a given $\mathrm{k}_{\mathrm{L}}$ a value that it is a key parameter for the results. To achieve this, to compare results and to know the impact of broader ranges of operation, the work with cold models looks very convenient $(6,7)$.

\section{MEASUREMENT OF GASES AND CONTROL APPLICATIONS}

The main difficulty to have a good control system from data evolution of the liquid phase is the scarcity of measurements. Nevertheless there are other measurable variables, mainly in the outlet gases. Among them are gas temperature, electric conductivity, noise and gas concentrations. Noise has been correlated in several works to foam and slag flooding. Other tools have been quoted such as an additional lance and the batch temperature measurements. The use of different

\section{TABLE VII: Effect of scrap and mineral additions on the} composition.

TABLEAU VII: Effet de la ferraille et des additions sur la composition.

\begin{tabular}{|l|c|c|c|c|c|}
\hline Element & Scrap & Dolomite & FluoSpar & Sinter & Lime \\
\hline Carbon & No & No & No & No & No \\
\hline Manganese & $\uparrow$ & $\uparrow$ & No & - & $\uparrow$ \\
\hline Silicon & $\uparrow$ & $\uparrow$ & No & $\uparrow$ & $\uparrow$ \\
\hline Sulphur & $\uparrow$ & $\uparrow$ & No & $\uparrow$ & $\uparrow$ \\
\hline Phosphorous & $\uparrow$ & $\uparrow$ & No & $\downarrow$ & $\uparrow$ \\
\hline FeO & $\downarrow$ & $\downarrow$ & No & - & $\downarrow$ \\
\hline Oxygen & $\downarrow$ & No & No & $\downarrow$ & $\downarrow$ \\
\hline Temperature & $\downarrow$ & $\downarrow$ & No & $\downarrow$ & $\downarrow$ \\
\hline
\end{tabular}
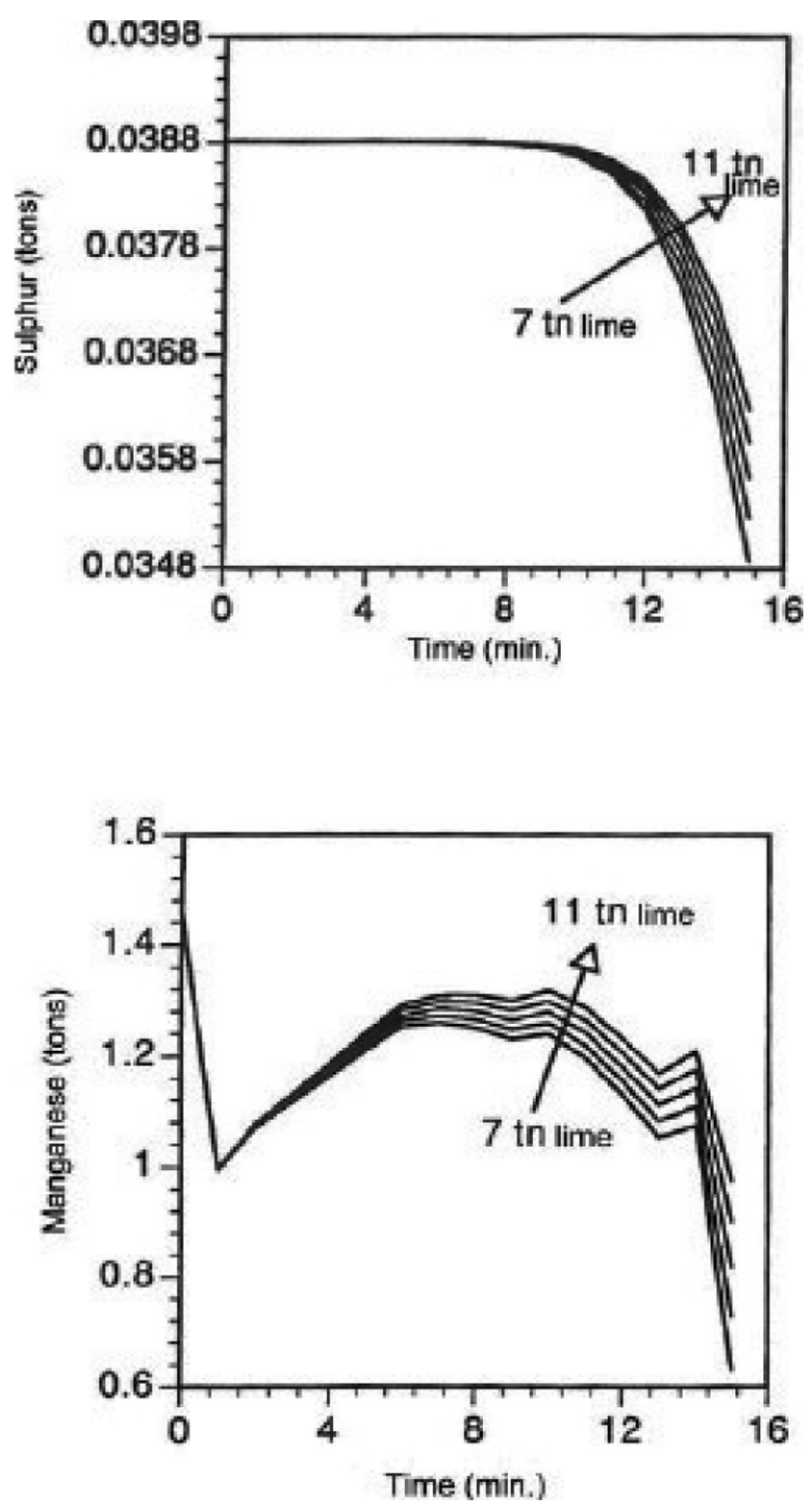

Fig. 7 - Trajectories of $\mathrm{Mn}$ and S for lime addition from 7 to 11 ton.

Fig. 7 - Evolutions du Mn et du S pour des additions de chaux de 7 et 11 tonnes.

methods determines also the type of control. Concentrations of $\mathrm{CO}$ and $\mathrm{CO}_{2}$ (besides $\mathrm{O}_{2}, \mathrm{~T}$ and $\mathrm{P}$ ) in the "outlet bell" (fig. 8) prove very useful because of their relation to $\mathrm{C}$ removal inside the reactor, and their continuous character.

In figure 9, one trajectory of the $\mathrm{CO}$ and $\mathrm{CO}_{2}$ measured in the gas outlet through the blowing is presented.

From these data and the knowledge of the $\mathrm{O}_{2}$ blown, with simple mass balances to the three species, the removal of $\mathrm{C}$ in the reactor and its concentration is obtained (fig. 10). Concerning the only prediction of $\mathrm{C}$, several proposals are now available, and when data are available, the errors of all the methods can be compared (11). 


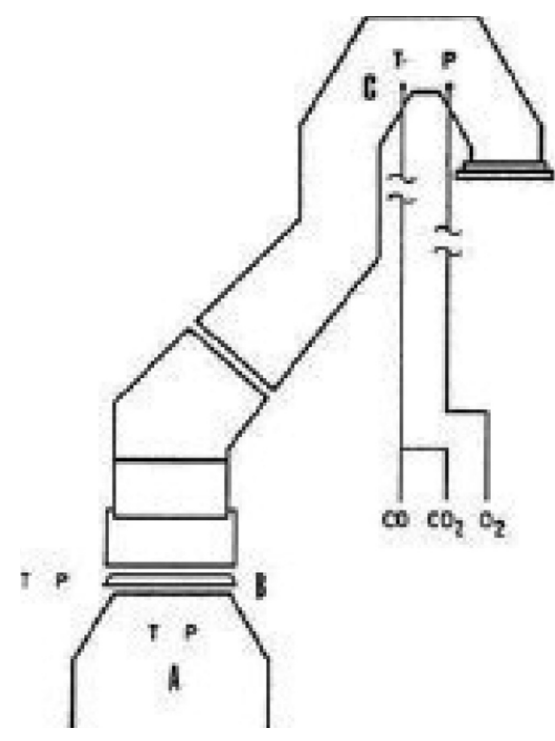

Fig 8 - Sampling points for $\mathrm{CO}, \mathrm{O}_{2}$ and $\mathrm{CO}_{2}$ in the outlet bell.

Fig. 8 - Points de prélèvement de $\mathrm{CO}, \mathrm{O}_{2}$ et $\mathrm{CO}_{2}$ dans la cloche.

\section{CONCLUSIONS}

Models to fit and then predict the concentrations of $\mathrm{C}$ and other components in the batch can be used with different extent of basic knowledge. The tested methods have included statistical approach and gas measurements applying stoichiometric calculations. Ever more complex mechanisms have to be considered when introducing the differential equations for the individual specific kinetics: first for the simultaneous balance for $\mathrm{C}$ and $\mathrm{Si}$, then for the balance of the main and

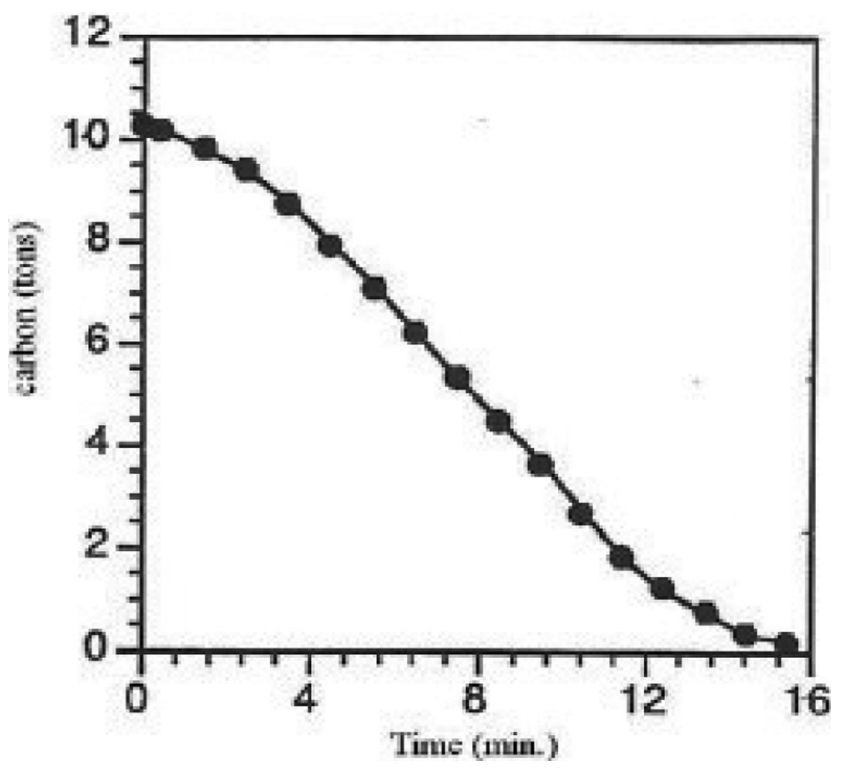

Fig. 10 - Carbon trajectory in the batch obtained from the gas concentrations obtained in the gas outlet.

Fig. 10 - Evolution du carbone de la coulée déduite des analyses des émissions de gaz.
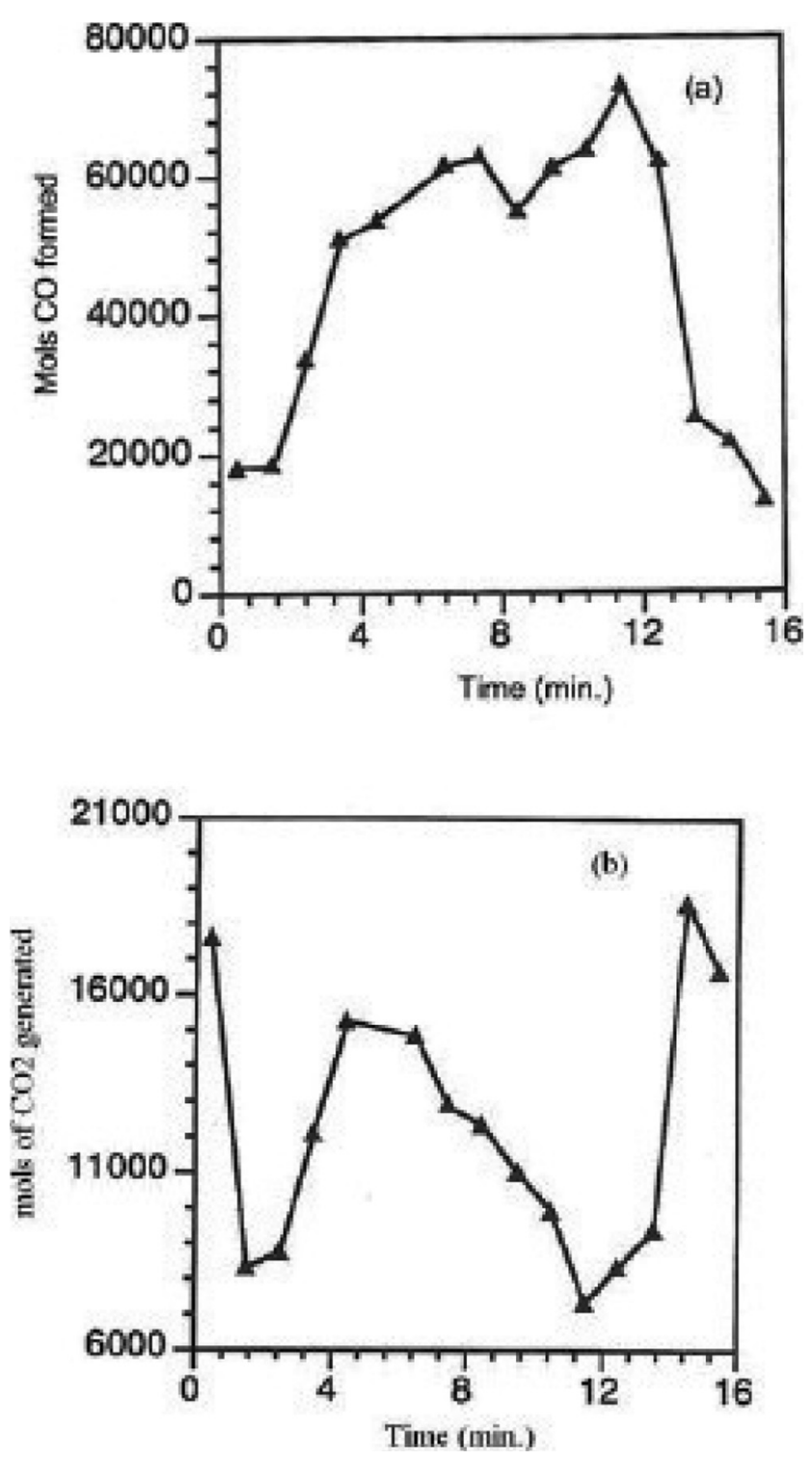

Fig. 9 - Evolution of $\mathrm{CO}$ and $\mathrm{CO}_{2}$ in the gas outlet.

Fig. 9 - Evolution de $\mathrm{CO}$ et $\mathrm{CO}_{2}$ dans la cloche.

secondary components, and finally for the introduction of the energy balance.

Besides, the determination of the different thermodynamic parameters involved in the model, has to be justified not only by the magnitude of the errors, but mainly by the scientific consistency of the assumptions, the relative magnitudes and the comparison with experiments in the laboratory and with cold models.

\section{ACKNOWLEDGEMENTS}

To the EU for the financial support and the research team of Ensidesa, Spanish Steel Company, (actually part of Arcelor) that have previously supported this project. 


\section{REFERENCES}

(1) SZEKELY (J.), THEMELIS (N.-J.) - Rate phenomena in process metallurgy, Ed Wiley \& Sons, New York, 1971.

(2) JOHANSEN (S. -T.) - Multiphase flow modeling of metallurgical flows, Experimental Thermal and Fluid Science, 26 , 2739-745, 2002.

(3) BLANCO (C.) - Analysis and control of the conversion process in LD steel, $\mathrm{PhD}$ thesis, University of Oviedo, 1992.

(4) YUGOV (P.-I.) - Mechanism and kinetics of optimized slag formation in an oxygen converter, Metallurgist, 49, 7-8, 2005.

(5) KITAMURA et al - Improvement of reaction efficiency in hot metal dephosphorization, Ironmaking and Steelmaking $29,(2), 121-124,2002$.

(6) BLANCO (C.), DÍAZ (M.) - Model of mixed control for carbon and silicon in a steel converter, ISIJ Int., 33, 757-76, 1993.
(7) MARTÍN (M.), RENDUELES (M.), DÍAZ (M.) - Global and local mixing determinations for steel converter analysis, Chem. Eng. Science, 60, 5781-5791, 2005.

(8) MARTÍN (M.), BLANCO (C.), RENDUELES (M.), DÍAZ (M.) - Gas-liquid mass transfer coefficients in steel converters, Ind. Eng. Chem. Res, 42, 4, 911-929, 2003.

(9) MARTÍN (M.), RENDUELES (M.), DÍAZ (M.) - Steel-Slag mass transfer in steel converter, bottom and top-bottom combined blowing through cold model experiments, Chem. Eng. Res \& Design, 83(A9), 1076- 1084, 2005.

(10) LIU et al - Physical modelling of slag splashing in converter, Ironmaking and Steelmaking, 30 (1), 2003, 36-42, 2003.

(11) KUZKINA (N. -N.), YU, KOFMAN (V.), BATLUK (V.-K.) - Effect of the converter steelmaking technology on the nitrogen content of steel, Metallurgist, 45, 3-4, 122, 2001. 